\title{
Chapter 16 \\ Taking Life Cycle Management Mainstream: \\ Integration in Corporate Finance and Accounting
}

\author{
Cornelis Theunis Van Der Lugt
}

\begin{abstract}
What does it take for life cycle management (LCM) to capture the attention of the financial community? LCM experts face a window of opportunity as technological progress and economic developments lead to greater interest in mainstreaming the sustainability agenda and integrating it in business decision-making. This includes new approaches to the assessment of impacts on Natural Capital, environmental management as well as annual corporate reporting. Having highlighted these, this chapter employs a Green Business Case Model to define ways in which life cycle applications can be employed to link with core financial indicators of special interest to investors. It describes three hypotheses to illustrate where LCM tools can best make a difference, positively affecting core financial value drivers. The author suggests three hypothetical pathways to capture the attention of investors, linking environmental life cycle costing (LCC) and financial, activitybased costing. These are complemented with company case examples. It draws lessons from past work on the business case as well research on environmental versus financial life cycle costing (LCC).
\end{abstract}

Keywords Accounting • Corporate finance $\bullet$ Life cycle assessment $\bullet$ Life cycle costing $\bullet$ Life cycle management $\bullet$ Life cycle thinking $\bullet$ Sustainability

\section{Evolution in Assessment, Management and Reporting Standards}

Technological progress and improved understanding of the impact of a growing world population on resource use globally has set the scene for a gradual transformation of environmental assessment, management and reporting tools over

C.T. Van Der Lugt $(\bowtie)$

Center for Corporate Governance in Africa, Stellenbosch University Business School,

Cape Town, South Africa

e-mail: cornis.lugt@usb.ac.za 
the last decade. While globalization and trade liberalization has led to greater integration in the world economy, it has also been accompanied by increasing fragmentation in production (see OECD 2012; Elms and Low 2013). The life cycle assessment (LCA) community has seen a lively debate on, for example, the value of deepening research to the level of product subsystems versus widening research through systems expansion (cf Curran 2013), as well as combining process-LCA and Input-output (IO) LCA to deal with the complexities of long supply chains and product chain organization (see Gereffi et al. 2005; Finnveden et al. 2009; Koh et al. 2013; Lake et al. 2014; Eriksson and Olsson 2011; Baumann 2012).

Furthermore, global financial crises as well as dramatic cases of corporate failure has led to renewed questioning of the role of corporate reporting. Frustration about information overload in annual reports and apparent lack of what is really material or strategic information has led to the birth of an integrated reporting movement. The International Integrated Reporting Council (IIRC) seeks to promote "integrated thinking", akin to "life cycle thinking". In defense of the GRI Guidelines, all its environmental indicators reflect a life cycle approach. This includes impacts at the end of the useful life of the product, especially important for life cycle management (LCM) as environmental life cycle costing (LCC) takes into account use- and endof-life phases and hidden costs (Klöpffer 2008). The LCA response to the integration challenge has been to define the emergence of life cycle sustainability assessment (LCSA) (see Finkbeiner et al. 2010; Guinee et al. 2011; Hellweg and Canals 2014)

Against this background of value chain complexity and initiatives in favor of integration, this chapter seeks to define pathways along which life cycle assessment (LCA) applications and life cycle thinking can be integrated with core business planning and strategic financial performance (Eun et al. 2009). Importantly, this chapter is not about moving from environmental and/or social LCA to economic LCA. Rather, it is about moving from environmental LCA to business finance and accounting. Its reflections will also be relevant for what integration in the form of sustainability LCA (a new integrated LCA or compilation of separate assessments) implies, and how life cycle sustainability assessment (LCSA) could be engrained in corporate financial planning.

\section{Linking Life Cycle Assessment with Financial Value Drivers}

The weighting of different impact categories and resource use in the impact assessment (LCIA) steps of LCA takes us to the heart of making the business case and linking it with corporate finance. This is where relative importance of impacts and dependencies are assigned, where the level of significance is determined, where ultimately the question of financial materiality is asked from a business perspective. 
ISO recognizes that this involves subjective judgment, and is dependent on the overall goal of an LCA study (goal and scope definition). In the accounting and reporting domain, international standards from International Accounting Standard Board (IASB), IIRC (IIRC 2012, 2013), GRI and AccountAbility (AA1000) include recognized definitions of "materiality" and recommend procedures for determining "levels of significance" that involve various stakeholders to a greater or lesser degree.

Monetized costing provides an important way of weighing or prioritizing among various impacts and dependencies. A valuable field for making the link between LCA and business finance is life cycle costing (LCC), both financial LCC and environmental LCC (see Hunkeler et al. 2008; Reich 2005; Hunkeler and Rebitzer 2003). The former refers to financial economic analysis of a product or a function, in other words, conventional business financial analysis that would be done for investment decision-making considering the economic life cycle of the product or function. This contrasts with environmental LCC, which involves weighting the environmental impacts of an LCA system in monetary terms. Links between the two become evident when the environmental impacts have an economic impact on the system being analyzed, for example when environmental externalities are being taxed by local authorities. The environmental LCC may more scientifically reflect resource scarcities than the financial LCC, which when using mainstream economic system prices or market values for resources signal costs that may not adequately reflect real, absolute resource scarcities. This is where risk definition needs to be more science-based and reflect appropriate context. Furthermore, in as far as an investment decision for a specified number of years to come needs to be made in the face of uncertainty (such as future pricing or taxing of resource use or pollution), business managers can benefit from the application of real option (RO) theory in combination with LCA and LCC (cf Cucchiellaa et al. 2014).

Any attempt to integrate monetized values of significant life cycle impacts or dependencies in business decision-making has to address the indicators that are of greatest interest to chief financial officers (CFOs) and those who provide financial capital to enterprises. This is essential in making the business case, mapping out cause and effect relations between environmental or sustainability actions and financial results for the business. It can be illustrated by using a "Green Business Case Model" (Van der Lugt and Bertoneche 2013) that includes the core financial value drivers of special interest to financial managers.

The listed action areas and connectors included in the model (see Table 16.1) have been identified based on the review of over 60 research articles and business reports on the business case that have been published from 2002 to 2012 (see, for example, Margolis et al. 2007; Ambec and Lanoie 2007; Berger et al. 2007; EABIS 2009; Molina-Azorín et al. 2009; Business in the Community 2011). Considering the evolution of business case research over the last decade, it is evident that the indicators most commonly referred to can best be grouped in a three step model of (i) action areas, which lead to change in the area of what can be described as (ii) 
Table 16.1 The Green Business Case Model (columns 1-3), with additional references to LCM linkages (column 4)

\begin{tabular}{l|l|l|l}
\hline Environmental action areas & $\begin{array}{l}\text { Connectors: } \\
\text { lead indicators }\end{array}$ & $\begin{array}{l}\text { Financial value } \\
\text { drivers }\end{array}$ & LCM linkages \\
\hline Eco-design (DfE) & $\begin{array}{l}\text { Customer } \\
\text { attraction }\end{array}$ & Growth of sales & Product LCA \\
\hline Goods and services & $\begin{array}{l}\text { Brand value, } \\
\text { reputation }\end{array}$ & Duration of sales & Ongoing LCM \\
\hline $\begin{array}{l}\text { Standards (incl. life cycle) and } \\
\text { technologies }\end{array}$ & Innovation & Operating margin & LCC and CBA \\
\hline Supply chain management & $\begin{array}{l}\text { Operational } \\
\text { efficiency }\end{array}$ & $\begin{array}{l}\text { Investment in } \\
\text { fixed capital }\end{array}$ & $\begin{array}{l}\text { Maintenance, } \\
\text { Remanufacturing }\end{array}$ \\
\hline Education, training & $\begin{array}{l}\text { Human capital, } \\
\text { productivity }\end{array}$ & $\begin{array}{l}\text { Investment in } \\
\text { working capital }\end{array}$ & $\begin{array}{l}\text { Product service } \\
\text { systems }\end{array}$ \\
\hline Risk management & Risk profile & Cost of capital & Impact risks \\
\hline $\begin{array}{l}\text { Communications, reporting } \\
\text { (incl. stakeholder engagement) }\end{array}$ & $\begin{array}{l}\text { License to } \\
\text { operate }\end{array}$ & Tax rate & $\begin{array}{l}\text { LC-based } \\
\text { eco-taxes }\end{array}$ \\
\hline
\end{tabular}

precursor or lead indicators, change that eventually affect (iii) the financial value drivers. For each of the rows of indicators a cause and effect relation can be hypothesized. For illustrative purposes three of these are discussed below, with examples including special reference to LCA applications. It shows pathways of making the connection between greening actions and business financial performance.

\subsection{Growth of Sales}

Hypothesis for Sales Growth As market and regulatory demand for sustainability grows, the business that (i) makes effective use of design for sustainability and delivers greener products and services will be in a position to (ii) boost its innovation ability and attract more customers, which (iii) will show positive results in its growth of sales.

This argument aligns with the proposition by management experts that sustainability has become the key driver of innovation, in new products and services as well as business models (Nidumolu et al. 2009). Take-up of such products and services is boosted by, among others, more reliable information (e.g., labeling). Of special significance for LCA-based product innovation, and LCM more broadly, is survey research by McKinsey with Boston College (2009) which cited innovation, new products, new customers, and new markets as specific areas where sustainability factors have demonstrable impact on overall organizational growth. The challenge for the LCM community is to illustrate how LCA can be employed in a convincing manner to deliver products with reliable certifications and product infor- 
mation. It may, for example, be asked whether the price of the product includes costs associated with the use and the end-of-life phases of the product. In as far as the greener product may be more expensive, consumers need education and guidance to realize that over the full life cycle the product is in fact cheaper. To start with, the LCA opportunity starts at the design phase. Eco-design has often been cited as one of the obvious applications of life cycle thinking, integrating business economics and the environmental sciences. Consider, for example, that most of the resource requirements and environmental impacts of products are predetermined during their design stage.

The need for reliable labels and certifications applies not only to manufactured products. Consider agrifood products and increasing consumer concern about where (local versus imported) and under what conditions (organic or sustainable) they have been produced. The retailer sector provides growing evidence of the use of green labels and the ability of major corporations to report impressive growth in the sales of such products. Whole Foods Market (2011), a Fortune 500 company and largest retailer of natural and organic foods in the USA, has seen its sales grow from $\$ 92.5$ million in 1991 to $\$ 10.11$ billion in 2011, at a compounded annual growth rate of $26 \%$.

Topical examples of product innovation and LCC can be found from companies such as Procter \& Gamble (P\&G), General Electric (GE), Puma, and Baxter. Mindful that consumers' product use causes the highest level of water consumption related to a detergent product's life cycle, P \& G in 2007 switched all of its liquid detergents to a compact formula. By fall 2008, its Fabric Care and Home Care segment had seen a $10 \%$ increase in net sales growth (CERES and Pacific Institute 2009). Launched in 2005 as an explicitly cleantech labeled product range, the Ecomagination products of GE reached sales of US\$18 billion in 2009 - the size of a Fortune 150 company. GE has since predicted that revenues of Ecomagination products will grow at twice the rate of total company revenues over the coming 5 years (Porter and Kramer 2011). By 2015 the company reported sales revenue of Ecomagination products since 2005 was US $\$ 160$ billion.

In 2010, the sporting goods company PUMA published an environmental profit and loss (EP\&L) account, providing a monetary value on life cycle environmental impacts along its entire supply chain. The methodology in doing this involved a hybrid I-O process LCA. It enabled the company assess its overall environmental impacts valued at EUR 145 million in 2010 and define its most significant environmental impacts, where these impacts mainly occur (tiers 3 and 4 of the supply chain), in which regions most of the impact occur (Asia Pacific) and how they are spread in its product portfolio (e.g., mainly related to footwear). Today its annual report includes a Sustainability Scorecard that gives performance data by product, factories and company. From 2010 to 2012 its global brand sales grew from EUR 2.86 billion to EUR 3.45 billion (PUMA 2012).

The EP\&L published by Puma can be compared with the Environmental Financial Statement published by healthcare company Baxter in its annual environmental reports since the mid-1990s. The statement by Baxter lists annual environ- 
mental costs as well as environmental income, savings or cost avoidance. These reflect actual costs associated with activities such as pollution control, environmental fees for packaging, energy and water consumption. The Baxter statement rather reflects an approach akin to financial LCC, as opposed to the Puma statement that reflects the application of an environmental LCC. In 2012, Baxter ranked number 86 in the Corporate Knights list of "Global 100 Most Sustainable Corporations in the World" and for the 11th year was recognized as the Medical Products Industry Leader of the Dow Jones Sustainability World Index (Dhanda 2012). In its annual sustainability report Baxter prominently discusses the application of LCA and LCM including the conducting of product sustainability reviews (PSRs) that are described as providing the foundation for its sustainable product design. From 2008 to 2012, its annual sales revenues grew from US\$12.3 billion to US\$14.2 billion.

\subsection{Duration of Sales}

Hypothesis on Duration of Sales Growth The business that (i) introduces greener goods and services to the market, backed up consistently by recognized standards and labels, will (ii) reap the benefit of greater brand value and reputation, enabling it (iii) to sustain a good growth of sales with longer duration.

Any assessment of the financial health of a company needs to consider not only its "growth of sales" over the last quarter or year. It also has to consider the "duration of sales," for example, trends over a 5-year period. The ability to not only reach new customers but also maintain their loyalty and trust over the longer term is determined by a range of factors, all of which serve to build company or product brand value. This is where credible use of LCM tools and consistent communication of product performance based on LCA applications can be critical. It may also require applying LCM in developing or assessing not just individual products or product lines but a broader product portfolio with longer-term customer relations in mind.

From surveys of senior managers and investment professionals in global firms it is evident that brand and corporate reputation tends to be a key area where they see a business case. The concern with reputation implies not only business to consumer (B2C) but also business to business (B2B) relations. If brand is to provide a guarantee of product safety and quality, the ongoing performance of all tiers of suppliers in the value chain becomes critical. This presents fertile ground for applying life cycle methods in business value chains. Accompanying the attributes of greener products and services with greener standards in operations will serve to further boost the reputation of both product and company (cf Iraldo et al. 2014).

A survey in 2012 of 1,375 consumers and 575 senior executives of companies with revenues of over US\$500 million in China, Brazil, the USA and the UK found that $78 \%$ of respondents indicated they do not buy a product if they do not like the parent company (Weber Shandwick and KRC Research 2012). In addition, $67 \%$ 
indicated they examine product labels to find the parent company, and $56 \%$ would think twice if they could not find information about the company behind it. This illustrates possible limitations of only applying LCA to products, and the advantages of broadening the scope and applying life cycle thinking transparently to the broader enterprise.

Supporting duration of sales and continual improvement in quality is of course the training of employees and incentives for management in the use of LCM tools. Consider the example of life sciences and material sciences company Royal DSM (2010/2012). It links almost one-quarter of management compensation to the company's performance in eco-product development, energy efficiency and employee engagement. The company's 23,000 employees deliver annual net sales of more than $€ 9$ billion. ECO+ products constituted $40 \%$ of running business sales in 2010 and $43 \%$ in 2012.

\subsection{Operating Margin and Capital Expenditure}

Hypothesis on Profit and Capital Through (i) the use of recognized standards and cleaner technologies in its own operations to use resources more sustainably, as well as advancing those through its supply chain, a business can (ii) improve its operational efficiency - its ability to turn inputs into productive outputs in a costeffective manner - as a result of which (iii) it will improve its net profit margin and optimize its capital expenditure.

The key role of resource efficiency in operations and its impact on earnings before interest and taxes (EBIT) is recognized today, especially in industries in highly competitive markets such as information and communications technology, car manufacturing and consumer goods. Traditional analysis on the business case has tended to start off by highlighting cost savings, in particular savings related to energy use. In as far as resources are wasted and polluting emissions not avoided, business earnings will additionally be taxed in more economies world-wide. An analysis of the carbon exposure of an emerging markets investment portfolio benchmarked against the S\&P/IFCI LargeMidCap Index is illustrative. For 16 firms from emerging markets, analysis by Trucost (2010) has found that at US\$108 per metric ton of carbon dioxide equivalent $\left(\mathrm{CO}_{2} \mathrm{e}\right)$ by 2030 , carbon costs could equate to more than $100 \%$ of their EBIT (Carbon Disclosure Project 2010).

The costs of penalties for inaction contrasts with the benefits of preventative action. 3M has been running its Pollution Prevention Pays (3P) program for 40 years by 2015. In 2013 it estimated that since its inception the program has served to avoid 1.9 million metric tons of pollutants (waste, air and water pollution) and saved the company nearly US $\$ 1.8$ billion based on aggregated data from the first year of each 3P project (3M Sustainability Report 2014). LCM is applied to all its products. Furthermore, LCM evaluation as a required component of its New Product Introduction process. It is also building on its LCM experience to develop new sus- 
tainability solutions. Clearly this is no longer just about operational efficiency in the name of cost savings. More companies have also started to focus on increased revenues and competitive market position.

McKinsey (2011) has found that $70 \%$ of productivity opportunities today have an internal rate of return (IRR) of more than $10 \%$ at current prices. As a result, some argue that business finds itself in the era of the Resource Revolution (Heck and Rogers 2014). Alongside opportunities are growing risks related to resource use. The cost of raw material inputs is impacted by growing natural resource constraints, which puts at risk the profit margins and EBIT of a range of sectors. The past decade alone has reversed a 100-year decline in resource prices. Analysis of fast-moving consumer goods companies by WRI and ATKearney in the late 2000s considered the impact of commodity price rises (Callieri et al. 2008). They calculated an ecoflation scenario in which natural resource constraints cause a reduction of $13-31 \%$ in EBIT by 2013, and $19-47 \%$ by 2018 for companies that do not develop strategies to mitigate the risks posed by environmental pressures. Examining data from six firms with a global presence in producing food, beverages, personal care and household care items, they found that, on average, raw materials and packaging costs each equaled $15 \%$ of revenues (Von Falkenstein et al. 2010).

What then is the connection between cleaner production standards, operational efficiency and capital expenditure? Improved efficiency in the use of resources will drive more optimal use of fixed assets (e.g., land, buildings, equipment, machinery, vehicles). A challenge for the LCM community is to define how life cycle management of fixed assets can bring efficiency improvements through the use of approaches such as remanufacturing. There also exists an LCM opportunity with respect to working capital, a financial value driver with respect to which limited research on the green business case exists. It is related to the use of product service systems (PSSs) in the form of leasing rather than buying equipment, which can bring significant savings alongside its environmental benefits. This includes efficiencies due to services provided at scale, onsite or offsite, by an external business partner (see Willard 2012). In how far is LCA able to capture such benefits with different system boundaries involved? If LCA and LCC can quantify the benefits of PSSs in physical and monetary terms, the findings will also be of special relevance to working capital expenditure. PSS-related efficiency improvements can serve as a driver for innovation in the way inventory and customer or supplier relations (receivables or payables) are managed.

\section{Conclusion}

Amidst greater interest in how enterprises use different types of capital and generate value in a sustainable manner, LCM has to prove its value by illustrating linkages with corporate finance and strategic performance. Considering the core financial value drivers highlighted in this chapter, the necessary contribution of LCM is summarized below: 
- Sales growth and its duration: LCM has to be used effectively in the design of products or product portfolios, services and business models that are convincingly sustainable. LCC experts have recognized that new business models may be required to develop more integrated (not fragmented) value chain systems (Swarr et al. 2011). Mindful of the lead indicators of customer attraction and brand reputation, LCA applications also have to be used credibly and consistently in a manner that enables the communication of reliable information via labels and the like to customers.

- Operating margin: The use of LCM standards, internally and through supply or value chains, need to effectively promote innovation and operational efficiency in order to boost operating margins. This is not simply about short-term profit. It is about defining avoided and opportunity costs in making business approaches that secure the longer-term sustainability of profit and cash flows.

- Investment in fixed and working capital: LCA experts need to consider in how far their methodologies can be used to define the value of closed loop manufacturing (CLM), in particular remanufacturing, as well as product service systems (PSSs) in enabling more optimal and sustainable capital expenditure. CLM and PSSs are highly under-estimated.

- Cost of capital: LCM needs to be effectively integrated with risk management, helping broadly to define hot spots in value chains and, specifically, through the collection of bottom-up data, risks of various kinds (including operational and regulatory) that may be associated with specific products, operations and organizational entities. In addition, the providers of financial capital need to be educated about the meaning of LCA findings.

- Tax rate: The LCA community needs to illustrate how its research can be used by regulators to define convincing eco-tax regimes that succeed to reward early adopters and penalize enterprises that persist with damaging products, services and business models.

It is theoretically convenient to state that environmental LCC is different from financial LCC and activity-based costing (ABC) in management accounting (cf Rebitzer and Nakamura 2008). One is focused on the costs of environmental damage and the other on business costs. It is, however, imperative today to define the link between these two and not leaving this to regulators. It means that LCA experts will need to support cost benefit analysis in which the incentives and cost structures for individual actors involved in whole life cycle systems or value chains are assessed. Furthermore, analysis will also need to show an ability to assess future costs and benefits likely to occur in the short, medium or long term. While seeking to meet these expectations, the LCM community will need to take cognisance of the preference among the mainstream investment community for "using a handful of the most important indicators and proxies to capture risk (that) can minimize complexity" (IIRC 2012). The three hypotheses examined in this chapter suggest pathways to capture the attention of investors in tackling this difficult task. 
Open Access This chapter is distributed under the terms of the Creative Commons Attribution Noncommercial License, which permits any noncommercial use, distribution, and reproduction in any medium, provided the original author(s) and source are credited.

\section{References}

3M (2014) Sustainability report. http://solutions.3m.com/wps/portal/3M/en_US/3MSustainability/Global/Environment/3P/. Accessed 12 Feb 2015

Ambec S, Lanoie P (2007) Does it pay to be green? A systematic overview. Acad Manag Perspect 22(4):45-62

Baumann H (2012) Using the life cycle approach for structuring organizational studies of product chains. In: 18th greening of industry network conference, Linköping, 22-24 Oct 2012

Berger I et al (2007) Mainstreaming corporate social responsibility: developing markets for virtue. Calif Manage Rev 49(4):132-157

Boston College Centre for Corporate Citizenship (2009) How virtue creates value for business and society: investigating the value of environmental, social and governance activities. Carroll School of Management, Boston

Business in the Community (2011) The business case for being a responsible business. BITC, London

Callieri C et al (2008) Rattling supply chains: the effect of environmental trends on input costs for the fast-moving consumer goods industry. World Resources Institute (WRI)/A.T. Kearney, Washington, DC

Carbon Disclosure Project (2010) Carbon disclosure project 2010 - global 500 report (written by PWC). CDP, London

Coalition for Environmentally Responsible Economies (CERES) and the Pacific Institute (2009) Water scarcity and climate change - growing risks for business and investors. Ceres and Pacific Institute, Boston

Cucchiellaa F, D'Adamoa I, Gastaldia M, Koh L (2014) Implementation of a real option in a sustainable supply chain: an empirical study of alkaline battery recycling. Int $\mathrm{J}$ Syst Sci 45(6):1268-1282

Curran MA (2013) Life cycle assessment: a review of the methodology and its application to sustainability. Curr Opin Chem Eng 2:273-277

Dhanda K (2012) Case study in the evolution of sustainability: Baxter International Inc. J Bus Ethics. doi: 10.1007/s10551-012-1565-2

Elms DK, Low P (eds) (2013) Global value chains in a changing world. WTO with Fung Global Institute (FGI) and Nanyang Technological University (NTU), Geneva

Eriksson T, Olsson D (2011) The product chains of rare earth elements used in permanent magnets and NiMH batteries for electric vehicles. ESA report 2011:8. Chalmers University of Technology, Göteborg

Eun JH, Son JH, Moon JM, Chung JS (2009) Integration of life cycle assessment in the environmental information system. Int J Life Cycle Assess 14:364-373

European Academy for Business in Society (EABIS) (2009) Sustainable value. EABIS with Cranfield University School of Management, SDA Bocconi School of Management, Vlerick Leuven Gent Management School, Brussels

Finkbeiner M, Schau EM, Lehmann A, Traverso M (2010) Towards life cycle sustainability assessment. Sustainability 2:3309-3322

Finnveden G et al (2009) Recent developments in life cycle assessment. J Environ Manage 91(1):1-21

Gereffi G, Humphrey J, Sturgeon T (2005) The governance of global value chains. Rev Int Polit Econ 12(1):78-104 
Guinee JB et al (2011) Life cycle assessment: past, present and future. Environ Sci Technol 45(1):90-96

Heck S, Rogers M (2014) Resource revolution. Amazon/McKinsey, Seattle

Hellweg S, Canals LM (2014) Emerging approaches, challenges and opportunities in life cycle assessment. Science 344:1109-1113

Hunkeler D, Rebitzer G (2003) Life cycle costing - paving the road to sustainable development? (Editorial). Int J Life Cycle Assess 8(2):109-110

Hunkeler D, Lichtenvort K, Rebitzer G (eds) (2008) Environmental life cycle costing. CRC Press, Boca Raton

International Integrated Reporting Council (IIRC) (2012) Capturing the experiences of global business and investors. The pilot programme 2012. IIRC, London

International Integrated Reporting Council (IIRC), Association of Chartered Certified Accountants (ACCA) and Netherlands Institute of Chartered Accountants (NBA) (2013) Capitals background paper. IIRC, London

Iraldo F, Testaa F, Bartolozzia I (2014) An application of life cycle assessment (LCA) as a green marketing tool for agricultural products. J Environ Plann Manag 57(1):78-103

Klöpffer W (2008) Life cycle sustainability assessment of products. Int J Life Cycle Assess 13(2):89-95

Koh L, Genovesea A et al (2013) Decarbonising product supply chains: design and development of an integrated evidence-based decision support system - the supply chain environmental analysis tool (SCEnAT). Int J Prod Res 51(7):2092-2109

Lake A, Acquayeb A, Genovesea A, Kumara N, Koh L (2014) An application of hybrid life cycle assessment as a decision support framework for green supply chains. Int J Prod Res, doi:10.1080/00207543.2014.951092

Margolis J, Elfenbein HA, Walsh JP (2007) Does it pay to be good? A meta-analysis and redirection of research on corporate social and financial performance. Harvard University working paper, July 2007

McKinsey \& Co (2011) Resource revolution: meeting the world's energy, materials, food, and water needs. http://www.mckinsey.com/insights/sustainability/resource_revolution

Molina-Azorín JF et al (2009) Green management and financial performance: a literature review. Manag Decis 47(7):1080-1100

Nidumolu R, Prahalad CK, Rangaswami MR (2009) Why sustainability is now the key driver of innovation. Harv Bus Rev. https://hbr.org/2009/09/why-sustainability-is-now-the-key-driverof-innovation

Organization for Economic Cooperation and Development (OECD) (2012) Mapping global value chains. Policy dialogue on aid for trade. Document TAD/TC/WP/RD(2012)9. OECD, Paris

Porter M, Kramer M (2011) Creating shared value. Harv Bus Rev. https://hbr.org/2011/01/ the-big-idea-creating-shared-value

Puma (2012) Annual business and sustainability report. Puma, Herzogenaurach

Rebitzer G, Nakamura S (2008) Environmental LCC. In: Hunkeler D, Lichtenvort K, Rebitzer G (eds) Environmental life cycle costing. CRC Press, Boca Raton, pp 35-57

Reich MC (2005) Economic assessment of municipal waste management systems - case studies using a combination of life cycle assessment (LCA) and life cycle costing (LCC). J Clean Prod 13(3):253-263

Royal DSM (2010/2012) Integrated annual report 2010/2012. Royal DSM N.V, JH Heerlen

Swarr TE, Hunkeler D, Klöpffer W, Pesonen H-L, Ciroth A, Brent AC, Pagan R (2011) Environmental life-cycle costing: a code of practice. Int J Life Cycle Assess 16:389-391

Trucost (2010) Carbon risks and opportunities in emerging markets - Trucost study on the exposure of different regional equity strategies to carbon costs. Trucost Plc, London

Van der Lugt CT, Bertoneche M (2013) Finding the God particle of the sustainability business case: greener pastures for shareholder value. Harvard Business School finance working paper no 13-072 (HBS 2013) 
Von Falkenstein E, Wellenreuther F, Detzel A (2010) LCA studies comparing beverage cartons and alternative packaging: can overall conclusions be drawn? Int J Life Cycle Assess 15:938-945 Weber Shandwick, KRC Research (2012) The company behind the brand: in reputation we trust. Weber Shandwick, New York

Whole Foods Market Inc (2011) Form 10-K, filed. www.wholefoodsmarket.com/company-info/ investor-relations. Accessed 1 Mar 2015

Willard B (2012) The new sustainability advantage: seven business case benefits of a triple bottom line. New Society, Gabriola Island 